\title{
Kirkelig demokrati under korona-pandemien
}

\author{
En studie av valgte kirkelederes delaktighet i beslutninger om \\ tiltak i Den norske kirke
}

Erling Birkedal \& Harald Askeland

MF vitenskapelig høyskole \& KA; Høyskolen i Østfold

\begin{abstract}
The article examines the conditions of democracy in the Church of Norway during the corona pandemic in 2020-2021. The focus is on the decision-making process with the church's own infection control supervisor, especially regarding the participation of elected leaders. The article is based on interviews and surveys among church leaders, as well as selected documents. The material is analyzed from three perspectives, which have also been trends in the church in recent years: democratization, corporatization, and professionalization.

The analysis shows that there has been good coordination between employed leaders at all levels in the church, during the pandemic. The collaboration mainly seems to have worked well. Decision-making processes have emphasized consensus. Some of the employees have also been given a clearer role of responsibility.

However, democracy has played a withdrawn role during the pandemic, where most decisions are made by employed leaders. Most elected local leaders seem to be satisfied with this withdrawn role. Among regional and central elected leaders, there is a clearer wish that this should have been discussed, and that the elected leader should have had a more prominent role. This delimitation of the scope of democracy can partly be understood in terms of the pandemic's distinctiveness, with the need for quick decisions and action. At the same time, there is reason to believe that this limitation of democracy relates to traditions and understanding of the church's democracy in general. In part, church democracy has been seen as a "meeting democracy", with emphasis on the decision itself, while implementation is left to the employees. At the same time, a lack of time or an institutionalized role of representative has pulled in the same direction. This article contributes to further reflection on the role of democracy in the Church of Norway.
\end{abstract}

Keywords: Church Democracy, Democratization, Corporatization, Professionalization 


\section{INTRODUKSJON}

Pandemien rammet hele verden i første kvartal i 2020 - og varte lenge. I denne pandemien har det vært store endringsprosesser for alle samfunnsinstitusjoner og organisasjoner, ikke minst for dem som har som formål å samle mennesker. Kirker og trossamfunn måtte i perioder stenge nærmest all virksomhet, med unntak av mindre grupper i kritiske situasjoner, som begravelser. Denne artikkelen tematiserer de endringer og beslutningsprosesser som skjedde i Den norske kirke, med særlig vekt på folkevalgtes rolle i perioden.

Vi går ut fra at krisetid generelt setter preg på organisasjoner og institusjoner i samfunnet. Det er gjerne i krisetider organisasjoner blir utfordret, og gjerne med langsiktige virkninger. Når vi analyserer det som skjedde i Den norske kirke i koronatiden, ser vi dette $\mathrm{i}$ lys av noen sentrale utviklingstrekk $\mathrm{i}$ kirken som institusjon de siste årene. Den norske kirke, samt soknene som grunnenheter, er blitt selvstendiggjort i forhold til offentlige organer. Det kirkelige demokrati og videre demokratisering er på dagsorden, og kirken har i likhet med andre institusjoner hatt en økende profesjonalisering (Sirris et al., 2021.) Med demokrati og demokratisering som tilnærming tenker vi på hvilken måte de demokratisk valgte organ og ledere er involvert i beslutningsprosesser. Er demokratiet aktivert eller satt på vent i pandemien, eventuelt med hvilken begrunnelse? Korporativisering setter søkelys på en utvikling i retning av at kirken fremstår som en sammenhengende organisasjon, en «organisasjonsgjøring». Har pandemien ført til en mer samlende organisasjonsledelse i pandemien? Med profesjonalisering tenker vi at det legges vekt på at det er spesifikke stillingskategorier med bestemte kvalifikasjonskrav som håndterer ulike oppgaver. Har det vært spesialister eller spesifikke stillingskategorier som har håndtert pandemien, og eventuelt hvorfor? Disse tre utviklingstrekk eller perspektiver på institusjonen er en ramme for vår analyse og drøfting i denne artikkelen. Vi legger vekt på demokratiperspektivet.

Målet med artikkelen er å gi innsikt i hvordan kirkens ledere (ansatte og demokratisk valgte), sentralt, regionalt og lokalt, har ledet den kirkelige virksomhet under koronapandemien. Smittevernveileder for Den norske kirke, som har vært gjeldende for ulike perioder i løpet av pandemien, er offentlig tilgjengelig på kirkens nettsider. ${ }^{1}$ Vi har ikke analysert innholdet $i$ disse, men er opptatt av prosessen som har vært forut og rundt disse veilederne. Vi har oppmerksomhet på hvem som har tatt ansvar, hvordan beslutninger er tatt og hvordan dette er kommunisert videre. Har det utviklet seg bestemte «kommandolinjen» i en nødsituasjon, eller har en brukt ordinære rutiner? Vi ser spesielt på hvilken rolle demokratisk valgte ledere har hatt.

Vårt problemstilling er: Hvordan har kirkelige ledere håndtert beslutningsprosessen med smittevernregler under korona-pandemien, spesielt med tanke på valgte lederes medvirkning?

\footnotetext{
${ }^{1}$ Fra Kirkerådet: https://kirken.no/nb-NO/infotilmedarbeidere/ (19.10.2021). Fra KA: https://www.ka.no/nyheter/korona (19.10.2021).
} 


\section{RELEVANT FORSKNING OG LITTERATUR}

Det har vært forsket og skrevet en del om endring av kirkens praksis i løpet av pandemien, og da spesielt knyttet til digitalisering (se f.eks. Hodøl et al., 2021; Hodøl \& Sæbø 2021). Det har så langt vært gjort mindre forskning på hvordan kirken som organisasjon har håndtert pandemien. Som grunnlag for dette prosjektet har vi hentet inspirasjon og faglige momenter fra Coronarapport om folkekirken i Danmark, for arbeidet $\mathrm{i}$ første halvår 2020 (Folkekirkens Uddannelses- og Videnscenter, 2020). Dette er en relativt omfattende rapport fra første fase av pandemien i folkekirken, der en får beskrevet hvordan kirken arbeidet for å håndtere den nye situasjonen med smittevern. Det er spesielt første kapittel som omhandler kirken som organisasjon som er relevant for oss. Forskningsrapporten behandler imidlertid ikke direkte kirkens demokrati under pandemien, men viser at pandemien førte til en mer tydelig organisasjon. Det heter $i$ en av konklusjonen at: «Coronaperioden gjorde, at den forvaltningshierarkiske struktur af en række af vores informanter blev oplevet som mere tydelig end under normale omstændigheder» (s. 13). Lokalt er det prest og menighetsrådsleder som står for tolkning av de sentrale smittvernsregler, og ønsker samtidig klare meldinger fra sentralt hold: «dominerende oplevelse blandt menighedsråd og præster en følelse af at vente på afklaring og retningslinjer fra biskopperne og Kirkeministeriet» (s. 14). Prostene fikk en sentral rolle, som bindeledd mellom den sentral og lokale kirke: «Provsten spillede, særligt gennem telefonsamtaler, online- og fysiske møder, en betydningsfuld rolle i forhold til tvivlsspørgsmål om retningslinjerne på lokalt niveau, og udøvede herigennem sin tilsynsmyndighed på vegne af biskoppen. Provsterne blev opdateret på udmøntningen af retningslinjerne gennem hyppige onlinemøder med biskop og provstekollegen» (s. 14). Vi ser altså en tendens i retning av økt korporativisering i Den danske folkekirke under pandemien.

Vi har søkt etter forskningsbidrag fra både Danmark og de andre nordiske kirke om betingelsene for det kirkelige demokrati under korona-pandemien, men har ikke funnet noe som behandler dette direkte. Vi oppfatter at vårt bidra i så måte er et pionerprosjekt.

\section{TEORETISKE PERSPEKTIV}

Vi anlegger et organisasjonsteoretisk perspektiv, med spesiell oppmerksomhet på styringssystemer og beslutningsprosesser, samt hvordan disse trer i kraft i en krisesituasjon. Vi ser på organisasjoner som system og organisasjonen som rasjonell, men samtidig åpen og forholder seg til og blir påvirket av omgivelsene. Når vi omtaler en organisasjon som institusjon, tenker vi spesielt på at den er preget av både kultur, regler og normer. Ledelse av institusjoner blir sosialt strukturert, ut fra diskurs og tradisjon (Askeland, 2012, s. 121-126). I vår sammenheng tenker vi spesielt på hvordan kirken, med sine spesifikke verdier og kultur innretter seg for å tilpasse seg og mestre de utfordringer som oppstår ved pandemien.

Den demokratisering som preget samfunnslivet har også skjedd parallelt i kirken, om enn i noe mindre omfang (Askeland, 2001; Grimstad, 2021). Rådsstrukturen er bygget opp fra lokalt til nasjonalt nivå, og tiltaksorienterte, arbeidstakerorienterte og interesseorienterte organisasjoner har engasjert seg. Samtidig innebærer dette en 
erkjennelse av at kirken trenger en handlingsorganisasjon representert ved lederstillinger og administrative ressurser for at de kirkelige styringsorganene skal fungere. Når man i forskning om offentlige politiske lederroller ofte har omtalt dette som «administrasjonsparadokset», fokuseres det tydelig på skillelinjer mellom det politiske domene og administrasjonens (byråkratiets) rolle (Lo \& Vabo, 2020). Fra å søke etablere klare skiller, peker diskusjonen i retning av at om folkevalgte skal kunne influere i komplekse saksområder, må det til en mer jevnlig og kontinuerlig kontakt slik at politikerne sikres mulighet for å definere agenda og ha innspill til vurderinger mens administrasjonen faktisk forbereder saksområdet.

Selvstendiggjøringen av Den norske kirke, med opphør av selve statskirkeordningen, medførte et søkelys på demokrati i kirken. Fra kirkelige utredninger ble det vektlagt at kirkens organer ikke lenger ville hente myndighet fra offentlige organer, men få myndighet som medlemmenes organer og uttrykke det allmenne prestedømmets styringsansvar (Kirkerådets kirke/stat-utvalg, 2002). Fra statens side var styrking av demokratiet og økt valgdeltakelse sett som en forutsetning for å gi kirken mer selvstendighet. Dette ble konkretisert i demokratireformen, som skulle øke oppslutningen om kirkelige valg og dermed organenes legitimitet (Saglie \& Segaard, 2011).

Demokratidebatten berører tre sentrale dimensjoner i demokratiforutsetningene: Bredde, dybde og rekkevidde (Saglie \& Segaard, 2011, s. 157f). Bredde dreier seg om hvem og hvor mange som har rett og mulighet til å delta. Formelt ble kirkedemokratiets bredde institusjonalisert som samsvarende med det statlige borgerdemokrati ved menighetsrådsloven i 1920. Dybde handler om engasjement og informasjonsgrunnlaget. For denne artikkelen er det primært demokratiets rekkevidde eller omfanget av saker og temaer demokratiet legitimt tar avgjørelse om, som står i fokus. En ting er at demokratiske organer har blitt utviklet og framstår som kirkens sentrale styringsorganer. (Et annet forhold handler om kapasitet og arena for å ivareta vervet som folkevalgt leder. Det har blant annet vært liten tradisjon i kirke og menighet for at folkevalgte ledere har vært frikjøpt til å ivareta sitt verv (Sirris et al., 2021).

Beslutninger og beslutningsprosessen i folkevalgte, demokratiske organer, er i sterk grad knyttet til møter. Dette omtales eksempelvis i Håndbok for menighetsråd og kirkelig fellesråd som møteprinsippet: «Menighetsråd og kirkelig fellesråd treffer sine vedtak i møter» (Kirkerådet, 2019, s. 199). Samtidig kan det på avgrensede områder gis fullmakt til leder eller et arbeidsutvalg å treffe vedtak i saker. Ellers er det vanlig praksis at det er daglig leder (kirkeverge/direktør) som representerer virksomheten med basis i et delegasjonsreglement. Den offentlige politiske lederrollen er betydelig mer utviklet i kommunene, som det kan være nærliggende å sammenligne med. Ordføreren er i kommuneloven definert som rettslig representant for kommunen og vil ofte være den som møter eksterne gjester eller aktører og som fronter kommunale beslutninger i media. I stor grad henger dette sammen både med den formelle institusjonaliseringen av rollens ansvar, men også om at sentrale politikere i dag er frikjøpt til å skjøtte sitt verv på heltid. Denne rolleklarhet eller tyngde mangler i kirkelig sektor, selv om det også her er utarbeidet en egen håndbok for rådsledere (KA, 2020). Der tematiseres nettopp den rolle rådsledere har mellom møtene:

$\AA$ være demokratisk valgt leder i kirken har tradisjonelt ikke vært en utadrettet rolle. Få vet hvem som er rådsledere lokalt. Noen i kirken har vært opptatt av å styrke den lokale kirkelige «ordføren» rollen. Vi tror det av hensyn til 
demokratisk utvikling og legitimitet for avgjørelser i menighetsråd og fellesråd er viktig å ha fokus på dette. Ikke som et personlig behov eller prosjekt for lederne, men av hensyn til demokratiutviklingen i kirken. (...) For fellesrådsledere har utviklingen etter 1996 gjort møtene med kommunenes politiske ledelse til en slik viktig arena. Vi tror imidlertid det er viktig å aktivt arbeide med en synliggjøring på flere arenaer. Det dreier seg om å fronte saker i lokalpressen, jubileer, åpninger osv.

Også demokratiet og folkevalgte organer må ledes, noe som innebærer fokus på politisk ledelse (Masciulli, et al., 2016; Røiseland \& Vabok, 2020). I en norsk kontekst er det tidligere påvist at få egentlig søker ledervervet i kirkelige råd og at man i stor grad knytter sin lederrolle til rådets arbeid med en viss profilering utad mot lokalsamfunnet og i møtepunkter med kommunen (Askeland, 1998). Samtidig har de fokus rettet mot utvikling, men da mer som pådrivere for at ansatte ledere og medarbeidere følger opp vedtak og planer (Grimstad \& Askeland, 1999). Gjennom et nylig arbeid pekes det på at lokale folkevalgte organer i liten grad utøver styringsoppgavene, primært grunnet mangel på sekretariat og mangel på rollebevissthet (Sirris, 2021). Innen internasjonal litteratur om politisk lederskap, i den grad den kan overføres til en kirkelig kontekst, pekes det på at sentrale funksjoner er å fortolke utfordringer, utvikle svar på utfordringene samt å mobilisere ressurser og følgere for å bidra til løsning (Masciulli et al., 2016, s. 7). Samtidig svekkes muligheten for hierarkisk politisk ledelse ved utviklingen av en demokratisk kultur der innbyggere/medlemmer i økende grad forventer å være involvert i beslutning og implementering (Røiseland et al., 2020).

Innen beslutningsteori, er det nettopp lagt vekt på tid og sakspesifikk kompetanse som ressurser når det gjelder innflytelse i beslutningsprosessen. En slik prosess kan forstås som en sekvens (eller rekke) av overveielser og handlinger, som fører fram til en beslutning (Enderud, 1985, s. 10). I denne prosessen vil det være ulike faser, som identifisering av problem, utredning av alternativer og konsekvenser, selve beslutningen samt den videre iverksettelse. Med manglende tid og kapasitet vil rådsledere ha mindre innflytelse i prosessen, samt at de ofte heller ikke representerer rådet på offentlige arenaer eller i møte med kirkens medlemmer.

I tilknytning til de valgte perspektiver (demokratisering, korporativisering og profesjonalisering) hører også at kirken har institusjonalisert to ansvars- og arbeidsgiverlinjer. Kirkemøtet har overtatt ansvaret for gudstjenestelivet og prestetjenesten fra staten, mens de lokale kirkelige råd har ansvar for de fleste øvrige områder. Til dette ligger ansvar for kirke og gravplassforvaltning, samt trosopplæring, diakoni og kirkemusikalsk aktivitet. I relasjon til beslutningsprosessene innebærer dette blant annet at fellesrådets daglige leder og prost har ansvar for ulike områder. Mye fokus har i pandemien vært rettet mot antall tilstedeværende på gudstjenester og kirkelige handlinger, et område som ligger under Kirkemøtet og prestetjenesten. Ansvar for gudstjenestene som arrangement blir da også tillagt prosten og menighetsprest. Samvirke mellom de to lederlinjer er imidlertid noe det har vært sparsomt med forskning rundt. Denne artikkelen gir innsikt i dette saksfeltet. 


\section{MeTODE OG MATERIALE}

Datamaterialet fra denne studien en innsamlet gjennom en kombinasjon av kvalitative og kvantitative metoder. Det kvalitative materiale er samlet inn gjennom semistrukturerte intervju med utvalgte personer, og sentrale dokumenter. Dette er sentralkirkelige ledere (slik som preses, direktør og valgt leder i KR (Kirkerådet), KA-direktør (KA Arbeidsgiverorganisasjon for kirkelig virksomhet) og fagforeningsledere), regionale ledere (noen valgte ledere i BR (bispedøemmeråd) og noen proster), lokale ledere (utvalgte kirkeverger/daglig leder, leder av FR (Kirkelig fellesråd) og MR (menighetsråd) og noen sokneprester). ${ }^{2}$ Kirkerådet har stilt til disposisjon aktuelle dokumenter og korrespondanser der korona-pandemien har vært behandlet, blant annet alle utgaver av smittevernveiledere, nyhetsbrev, pressemeldinger og informasjonsmøter. Videre har vi hatt tilgang til en rekke eposter knyttet til «beslutningsprosessen», mellom ulike ansatte i KR, KA, BM (Bispemøtet), kirkeverge-laget, og mellom kirkens representanter og dialogen opp mot nasjonale myndigheter, som Helsedirektoratet og Folkehelseinstituttet, samt en del spørsmål og svar fra andre, bl.a. i den lokale kirke.

Det kvantitative materialet er innhentet gjennom et eget utviklet spørreskjema. Det ble sendt et nettbasert spørreskjema til ca. 330 valgte ledere av kirkelig fellesråd, i mai 2021. Det ble gjennomført to purringer, og vi fikk svar fra ca. $40 \%$ (130). Ved behandling ble informantenes e-postadresser fjernet før analysen begynte, slik at det ikke eksisterer noen kobling til informasjon om den enkelte informant. I dette spørreskjemaet var det også flere åpne spørsmål der informantene svarte utfyllende, med egne ord. I hovedsak er det data fra disse åpne spørsmålene, sammen med intervju, som danner grunnlag for analyse i denne artikkelen. Utsagnene ble først gjennomgått for sortering i klynger av sammenfallende mening, for så å bli utviklet til mer generelle kategoribetegnelser ut fra det samlede innhold.

\section{Krisehåndtering i Den norske kirke (Dnk) - en introduksjon}

For å gi et overblikk og innsikt i arbeidsprosessen med smittevern mm i den sentrale ledelse i Dnk i koronatiden, gir vi en kort oversikt over hvordan dette arbeidet foregikk. ${ }^{3}$ Dette gjelder spesielt det som skjedde i den sentrale kirkeledelse. Utfyllende analyse av informantenes egne vurderinger av dette arbeidet gis senere $\mathrm{i}$ artikkelen.

Alle hadde kort tid å forberede seg på før pandemien var et faktum. Noen kirkeledere hadde dagene før pandemien for alvor slo inn i Norge, reflektert litt over hva dette kunne bety for Norge og kirken. Men det ble ikke gjort noe planmessig arbeid. KA hadde i første del av mars sendt ut en del informasjon om smittevern knyttet til arbeid ved begravelser. Men det var ingen gjennomtenkt beredskap for kirken som helhet før regjeringen besluttet å «stenge ned samfunnet» 12. mars 2020. Dette ble en ny situasjon for alle. Det var en viss forvirring og stor frustrasjon i den første perioden. De sentrale ledere måtte håndtere smittevern i egen institusjon/avdeling, samtidig som

\footnotetext{
${ }^{2}$ Det er til sammen gjennomført litt over 20 semistrukturert intervjuet (en gruppesamtale), hvorav 10 lokale medarbeider, 4 regionale og 7 sentralkirkelige.

${ }^{3}$ En spesiell takk til Elbjørg Ekre, spesialrådgiver i KA, som har bidratt vesentlig til informasjon og kvalitetssikring av denne fortellingen. Hun var KA sin representant inn i den sentrale smitteverngruppen som utviklet og oppdaterte smittevernveilederen.
} 
man måtte informere til ulike ledd innad i organisasjonen, og gi ekstern/offentlig informasjon.

Det ble raskt klart at håndtering av pandemien krevde tett samarbeid mellom alle de sentralkirkelige instanser, Kirkerådet, Bispemøtet og KA. Daglig ledere i disse institusjonene fant hverandre raskt. Det var enighet om at det måtte være en samordnet sentralkirkelig forankring av kirkens håndtering og informasjon om smittevern. I den først fasen var det daglige møter mellom de sentrale aktører, i Kirkens Hus. Kontakt med ansatte ble ivaretatt gjennom de vanlige organer, som AMU, kontaktmøter med fagforeninger $\mathrm{mm}$. KR-direktør hadde hyppige møter med stiftsdirektører og biskoper de første ukene. ${ }^{4}$ Det ble tidlig etablert en grunnleggende holdning blant kirkens ledere at det er de offentlige myndigheter som har ansvar for smittevernreglene, og en viser stor tillit til at de tar faglig gode avgjørelser. Det argumenteres med at kirken har et kall til å bevare liv og helse og at det derfor er en del av kirkens samfunnsansvar å følge smittevernregler, og ikke presse grenser for det som er ansvarlig. En aksepterer en kirkelig «fastetid», ved å avstå fra vanlig fellesskap mm.

Kirken hadde beredskapsplaner for å håndtere krisesituasjoner, f.eks. når det skjer store ulykker. Men det var ingen planer for hvordan man skulle håndtere denne situasjonen, en langvarig krisesituasjon der alle kirker i praksis ble nedstengt, bare unntak for et lite antall mennesker samtidig. Man måtte finne ut av hvordan en kunne være kirke uten kirkebygg og uten å gjøre det en var vant til, samle mennesker. Kirkelederne måtte handle raskt, og ble i denne fasen ikke så opptatt av roller og hvem som gjorde hva, men man utnyttet hverandres ressurser best mulig for å finne praktiske løsninger. Det var de daglige lederne som utgjorde en ledergruppe/smitteverngruppen, som etter hvert ble supplert med et par saksbehandlere. Det ble også relativt raskt klart at det var tjenlig å ha god kontakt med ledelsen i den lokale kirke når man skulle utforme veiledere. Derfor ble leder av NKVL (kirkevergelaget) trukket inn i den sentralkirkelige ledergruppen. I tillegg ble også flere fagforeninger involvert $i$ arbeidet med smittevernveilederne. Det ble i oppstarten gjort en arbeidsfordeling, der KR hadde ansvaret for smittevernveileder for gudstjenester og kirkelige handlinger, mens KA hadde ansvaret for kirkelig undervisning, diakoni og kirkemusikk. Etter et par måneder hadde arbeidsprosessen med smittevernsveiledere kommet inn i rutine. Den første felles smittvernsveilederen, utgitt i mai 2020, bygde på tidligere veiledere for ulike virksomhetsområder utgitt av KA og KR. I perioden 8. mai 2020 - 7. juli 2021 ble det publisert $\mathrm{i}$ alt 11 smittevernveiledere (versjon 1.0-11.0. Til sammen 18 utgaver om en tar med oppdateringer av de ulike utgaver). ${ }^{5}$ Det var flere saksbehandlere, i KR og i KA, som arbeidet spesielt med utvikling av de ulike veilederne, mens all tekst som ble offentliggjort ble avklart og godkjent i sentral smitteverngruppe. Alle veilederne var også innom fagforeningene for utsjekk/kommentarer (som KUFO, Diakonforbundet, PF, CREO, Fagforbundet). KA utgav også på selvstendig grunnlag en rekke artikler knyttet til coronaviruset og kirkelig virksomhet. ${ }^{6}$

\footnotetext{
${ }^{4}$ Se KR Sak 18/20 fra 26. mars 2020: https://kirken.no/globalassets/kirken.no/om-kirken/slik-styres-kirken/kirkeradet $/ 2020 /$ mars $/$ protokoll $\% 20$ kirker $\%$ C $3 \%$ A 5 det $\% 20$ mars $\% 202020$.pdf

5 https://kirken.no/nn-NO/om-kirken/for-medarbeidere/infotilmedarbeidere/smittevernveileder $\% 20$ for $\% 20$ den $\% 20$ norske $\% 20$ kirke/endringslogg/

${ }^{6}$ https://www.ka.no/sak/article/1541399
} 
Det var en viss forvirring om hvordan man skulle forstå nasjonale regler, da kirken ikke hadde noen god forankring i statsapparatet. Kirken/trossamfunn ble ikke regnet som en egen sektor i regjeringens refleksjoner (Barne- og familiedepartement), men ble sett på som et underbruk til kultursektoren. Kirkens ledere måtte derfor bruke mye tid og krefter på å avklare ulike spørsmål med helsemyndighetene, som ikke umiddelbart hadde innsikt og kompetanse på kirkelig virksomhet. Det ble spesielt frustrasjon over at det ble oppfattet som at myndighetene «stenger kirkedøra» i større grad enn andre forsamlingslokaler. Dette kommer spesielt til uttrykk i debatten om fastmonterte stoler og benker. Enkelte kirkeledere mener at myndighetene her har foretatt overtramp mot religionsfriheten. Sent på høsten 2020 ble det møte med statsråden, og det ble deretter opprettet et felles kontaktutvalg for tros- og livssynssamfunn, med en representant fra KR, KA, NKR (Norges kristne råd), Pinsebevegelsen, STL (Samarbeidsråd for tros og livssyn) og fra muslimske trussamfunn. ${ }^{7}$

KR etablerte etter en tid månedlige «allmøter» der den sentrale ledelse presenterte nyheter og ga veiledning til regionale og lokale kirkeledere. ${ }^{8}$ Dette var åpne møter som ble presentert på kirkens nettsider, YouTube og Facebook-sider. Sentrale aktører på disse møtene var i oppstarten KR-direktør, KA-direktør, preses og av og til KVlagets leder og noen med spesialkompetanse. Det var ingen valgte ledere med på disse møtene. Etter hvert var det KR og Preses som tok over disse møtene, og de utviklet seg til å handle også om mer enn korona. Slike møter synes å bli en mer eller mindre fast rutine. Både KR og KA hadde i den intense pandemiperioden 2020-21 egne saksbehandlere som arbeidet med rådgivning overfor lokale ledere og svarte på henvendelser knyttet til smittevernsveiledere $\mathrm{mm}$.

De demokratisk valgte organ i kirken fikk andre rammebetingelser i koronatiden. Det var i all hovedsak digitale møter, både for MR, FR, BR og KR. Kirkemøtet i 2020 var opprinnelig planlagt i april, der en bl.a. skulle velge nytt Kirkeråd. Møtet ble imidlertid utsatt til oktober. Gammelt KR måtte sitte «på overtid» og nytt KR ble konstituert mer enn ett år etter kirkevalget i 2019. Kirkemøtet i 2021 ble forskjøvet til november. Alt dette ovenfor står som en innledende rammefortelling om deler av det sentralkirkelige arbeidet under pandemien.

\section{RESULTAT OG ANALYSE}

I dette kapitlet starter vi med å presentere analyse fra intervjumateriale fra sentrale, regionale og lokale ledere. Vi analyserer materiale ut fra de tre perspektivene vi har anlagt, demokratisering, korporativisering og profesjonalisering. Etter dette presenterer vi svar fra spørreundersøkelse blant fellesrådsledere. Her er det deres rolle som folkevalgte ledere som står sentralt. Slik kan denne analysen sees som en utdyping av perspektivet «demokratisering». Til slutt i dette kapitlet har vi også med noe fra dokumentanalyse som er relevant for vår problemstilling.

\footnotetext{
${ }^{7}$ Forkortelse som brukes i artikkelen; KR: Kirkerådet, KA: Kirkelig arbeidsgiver- og interesseorganisasjon, BR: Bispedømmeråd, FR: Kirkelig fellesråd, MR: Menighetsråd.

${ }^{8}$ https://kirken.no/nb-NO/om-kirken/for-medarbeidere/allmoter-for-alle-ansatte-i-den-norske- 


\section{Analyse av intervjumateriale}

\section{Demokratisering}

Tenkning blant ansatte ledere er at krisehåndtering i utgangspunktet er en administrativ oppgave. Smittevernregler oppfattes som en operasjonalisering, noe man bare må gjennomføre, og anses slik ikke som et politisk spørsmål der det gjelder å velge/prioritere. Det trekkes med dette opp en grense for demokratiets rekkevidde, at de valgte ledere ikke er del av beredskapsarbeidet. Samtidig påpeker de ansatte ledere at valgte organer holdes orientert. Arbeidsutvalget (AU) i KR var imidlertid tett på i første fase med relativt mange møter. ${ }^{9}$ Dette ble spesielt aktuelt når en måtte gjøre endringer i regelverk ang. liturgi, bruk av kirkeklokker mm, som var vedtatt av Kirkemøtet. AU behandlet også første utgave av smittevernveileder (utgitt 08.05.20). Disse vedtakene bekrefter at oppgaveansvar for gudstjenester og kirkelige handlinger ikke ligger til lokale folkevalgte organer, men er forankret i Kirkemøtet og ivaretas gjennom biskopens forordning av gudstjenester og lederansvar for prestetjenesten, der det går en linje via prosten.

Vi ser en tilsvarende begrensning av demokratiets rekkevidde på bispedømmenivå. BR-ledere har blitt holdt orientert av stiftsdirektør. Men disse ledere eller BR som helhet, har ikke vært delaktig i bispedømmenes veiledning overfor menigheter. Deres medvirkning har i hovedsak vært avgrenset til praktiske spørsmål om og gjennomføring av egne digitale møter. BR-ledere betraktes som ledere av møtet i rådet, og ikke som del av beredskapsteam. Beredskapsarbeidet på bispedømmenivå rapporteres ikke til BR-rådet, slik som arbeidet ellers, men BR-medlemmer blir orientert generelt gjennom direktørens muntlige orientering i de ordinære møter.

Vi registrerer ulike oppfatninger blant BR-ledere om i hvilken grad de tenker at de som folkevalgte burde mer vært involvert i prosessen med bispedømmets arbeid. Enkelte BR-ledere påpeker behovet for at demokratiets rolle i krisetider må drøftes. Det ble enda mer aktuelt ved at krisen varte lenge og hvordan man skal gjenåpne. En av lederne sier:

Nå har vi holdte på med krisehåndtering i over et år ... er det en del av normalen. Vi har ikke klart overgangen fra opplevelsen av krise våren 2020, og hvordan arbeide $\mathrm{i}$ «normaliteten» under pandemien. Vi har ikke klart å få de valgte råd inn i refleksjonen...

Informantene forteller om at lokale råd (FR/MR) i liten grad har vært delaktige $\mathrm{i}$ beslutningsprosesser. Dette bekreftes også av spørreundersøkelsen. En begrunnelse for at rådene har vært relativt passive, er at pandemien kom tidlig i valgperioden med nye medlemmer, før rådene hadde fått innarbeidet gode rutiner og funnet sin rolle. Samtidig tenker MR-ledere som er intervjuet jevnt over at det er opp til de ansatte å arbeide innenfor gjeldende regler, og få til så mye de kan. De opplever ikke at det er et

\footnotetext{
${ }^{9}$ Se protokoll fra Sak KR 37/20 i møtet 4.-5. juni 2020: https://kirken.no/globalassets/kirken.no/om-kirken/slik-styres-kirken/kirkeradet/2020/juni/protokoll\%20kirker\%C3\%A5det\%20juni\%202020.pdf og referat fra AU-møtet 4. mai 2020: https://kirken.no/globalassets/kirken.no/om-kirken/slik-styres-kirken/kirkeradet/2020/juni/kr 37320 protokoll krau 04.05.20.pdf
} 
handlingsrom som skaper behov for vedtak i MR. I en relativt stor menighet, med mange ansatte, sier MR-leder:

Vi har en av de ansatte med i rådet hver gang, og får slik god innsikt $\mathrm{i}$ arbeidet. Vi har en åpen og god dialog med de ansatte generelt. ... Vi forstår oss mest som et styre, og ikke en administrasjon.

Denne holdningen kan forstås som tillit fra de folkevalgte til de ansatte. Lokale valgte ledere viser også til at deres rolle ikke er tilrettelagt for å være tett på denne type beslutninger, som oftest må skje raskt og i samarbeid med andre. Samtidig vises det til at menighetsråd må behandle noen «følgesaker», som f.eks. revisjon av budsjett, bevilgninger til digitalt utstyr $\mathrm{mm}$.

Vi ser at det er noe uenighet i hvilken grad folkevalgte organer skulle være med på avgjørelse om å stenge/åpne kirker. Enkelte stiller spørsmål ved om presten alene kan ha ansvar for å avlyse gudstjenester, da det er MR/FR som har ansvar for HMS, selv om prest har ansvar for innholdet. En FR-leder som ble intervjuet ser at erfaringen under pandemien bør få konsekvenser for fremtidig organisering: «Om presten gjør noe med gudstjenesten får det følger for andre ansatte ... derfor er det behov for å se på struktur, beslutningsrekkefølge, tjenestevei mm - med korona-erfaringene som bakgrunn.»

Som omtalt ovenfor er det blitt en nyskaping med jevnlige digitale informasjonsmøter fra kirken sentralt, med bare ansatte ledere som aktører. Det har ikke, så langt vi kan se i vårt materiale, vært drøftet i fellesskap hvem som skal informere utad, eller om valgt leder bør være med. Det har bare blitt slik. Ansatte ledere har oppfattet dette som et faglig, ikke politisk arbeid. Valgt KR-leder har imidlertid ønsket å være med på noen av disse møtene, uten at det har blitt tilrettelagt for det. Hun nevner at det kan synes merkelig at valgt leder ikke er involvert $\mathrm{i}$ den offentlig informasjon, når kirken også er en demokratisk organisasjon med ca. 3,7 millioner medlemmer. Noen av de demokratisk valgte fremhever at når krisen har vært langvarig har det avdekket et behov for å avklare nærmere de demokratiske organers involvering i beslutningsprosesser. Det vises til pågående arbeid med kirkelig demokrati. ${ }^{10}$ Lokalt er det $\mathrm{i}$ all hovedsak prest eller kirkeverge som er «ansiktet utad». I enkelte menigheter med daglig leder, har denne hatt ansvar for offentlig informasjon. De valgte MR-ledere som er intervjuet er jevnt over bekvem med en tilbaketrukket rolle, slik det er vanlig i det jevne arbeidet ellers.

Oppsummerende kan vi si at valgte lederes rolle ikke har vært drøftet spesielt knyttet til pandemien. De lokalt valgte ledere synes å være tilfreds med en tilbaketrukken rolle. Blant regionale og sentrale valgte ledere er det tydeligere ønske om at dette burde vært nærmere avklart, og at det ville være naturlig at valgt leder får en mer fremtredende rolle. Samtidig viser dette at en tradisjonell rolle, der man har et møtepunkt som går mellom politiske organer og ansatte ledere, ikke $\mathrm{i}$ tilstrekkelig grad gjør at kirkens demokratisk valgte ledere kommer i inngrep med saks- og politikkutvikling på et tidlig nok tidspunkt.

\footnotetext{
${ }^{10}$ Det kirkelige demokrati er under vurdering av et eget utvalg, oppnevnt av kirkerådet i 2021, og skal levere sin rapport 27 januar 2022 (https://kirken.no/nb-NO/om-kirken/aktuelt/vil $\% 20$ styrke $\% 20$ og $\% 20$ utvikle $\% 20$ folkevalgtrollen $\% 20 i \% 20$ kirken/)
} 


\section{Korporativisering}

Vi ser at pandemien til en viss grad har stimulert til utvidet samarbeid og økt grad av sammenheng i kirke-organisasjonen. Det ble en rask samling og koordinering av det sentralkirkelige arbeidet (se ovenfor). Regionale og lokale ledere bekrefter at de har sett dette og anerkjenner det sentralkirkelige samarbeidet med felles smittvernsleder og informasjonsmøter. Vi registrerer noe forvirring i første fase av pandemien, men gjennomgående er det stor tillit mellom de ulike nivå i kirken.

Proster har blitt utfordret til å ta flere avgjørelser enn vanlig, da det dukket opp behov for det. Dette henger også sammen med korporative trekk, der ansvarslinjen for gudstjenesteliv og prestetjeneste følger av prostens lederansvar for prestene. Det er en forventning som har kommet både ovenfra (biskop/bispedømme) og nedenfra (prester og MR). Lokale forhold og størrelse på prosti synes å være avgjørende for $\mathrm{i}$ hvilken grad prost er blitt direkte involvert i lokale prosesser.

Vi ser at kirkeverger bruker det etablerte nettverket innen prostiet for å utveksle informasjon og samordne avgjørelser. Det synes spesielt viktig der det er «felles marked» for begravelser/begravelsesbyrå, slik at pårørende skal oppleve mest mulig ens praksis.

Når vi spør etter hvilke konsekvenser pandemien kan få for kirkelig organisering, peker sentrale ledere på viktigheten av at «organisasjonen henger sammen». En typisk uttalelse er: «Håper erfaringene får innvirkning på kirkelig organisering, at organisasjonen må henge sammen både vertikalt og horisontalt.»

Det er avdekket et behov for å rigge beredskapsarbeidet annerledes. Uklarheter $i$ ansvarsforhold bør bli enda klarere i fremtidig organisering nevnes av flere. Krisetider utfordrer og viser svakhet ved den autonome profesjonskulturen som er i kirken, hevdes det av enkelte sentrale ledere:

Vi har sett svakheter ved den autonome profesjonskulturen. Det er mange aktører som lagde sine egne greier og brukt energi på mye unødvendig - i stedet for å følge de regler som er laget av de som har kunnskap og har bestemt noe.

Lokale ledere fremhever behovet for tydelig lokal ledelse, noen som tar beslutninger og ikke bare tilrettelegger for prosesser. Nåværende delte ledelse blir spesielt krevende der det ikke er avklart hvem som er daglig leder.

Vi ser at korporativiseringen, at pandemien har medført behov for at kirken $\mathrm{i}$ større grad må fremstå som en sammenhengende organisasjon, peker i retning av en innsnevring av demokratiets rekkevidde. De ulike linjer for virksomhetsansvar og det lederansvar som følger, har krevd tydeligere samarbeid og koordinering. Ansatte framstår som de formelle ledere, noe som også følger av den rettsliggjøring som har vært rundt rollen som daglig leder. Daglig leder blir et virksomhetsorgan mellom styremøtene/møtene i rådet, og når saken er ferdig behandlet synes det unaturlig å trekke inn rådsleder for å representere og presentere, slik det ellers gjøres i kommune og stat. Når mye oppmerksomhet har vært knyttet til avvikling av gudstjenester og kirkelige handlinger, blir i særlig grad prostens lederrolle tydelig. Ansvaret for kirke- og kirkegårdsforvaltning samt arbeidsgiveransvar, tydeliggjør også kirkevergens lederrolle lokalt. Et nødvendig samarbeid har dels ført disse stillingene sammen, der folkevalgte organer i mindre grad er involvert. 


\section{Profesjonalisering}

Vi ser at pandemien har innvirket på de ansattes arbeidsoppgaver og roller. Samarbeidet mellom prost og kirkeverge har blitt satt på prøve på den måten at pandemien har vært med på å avklare ansvarsområder. Kirkevergen har ansvar for alle ansatte utenom prestene, og HMS-arbeidet i kommunen. Prosten har ansvar overfor prestene, og skal samvirke med kirkevergen. Prosten synes å ha blitt mer besluttende ledere overfor prestene, og ikke bare en støttende leder, i pandemien. Det har vært behov for å ta relativt raske beslutninger og ikke bare ha en rådgivende rolle, slik det har vært mest vanlig for prosten. En av prostene sier:

Jeg merket at jeg selv ble mer tydelig. ... Jeg opplever det tilsvarende på menighetsnivå, at daglige ledere har tatt mer autoritet, og fått mer autoritet som ledere. ... I stedet for å bare lede ved å være støttende, har pandemien skapt et behov for å være tydelig på beslutninger.

Dette henger igjen sammen med at det er det nasjonale rettssubjektet, representert ved prost og prest som har ansvar for gudstjenester/gudstjenestelige handlinger. Pandemien har vært med på å bevisstgjøre roller og ansvarsforhold her.

Pandemien har virket inn på ulik måte for ulike stillingskategorier. Det er noen som måtte fortsette med mye av det samme som tidligere - bl.a. knyttet til begravelser (prester, kirketjenere og gravere). Andre måtte i større grad stenge ned eller omstille seg (pedagoger, musikere, diakoner mm). Dette har også ført til en viss omrokkering av personer for å ivareta nødvendige tiltak og smittevern. For enkelte arbeidstakere har det vært krevende å erfare at renholdsansvar ikke har blitt utført av fagansvarlige renholdere, men blitt gjort av «hvem som helst», andre ansatte som har fått «ledig tid». Fagforeningsledere etterspør partssammensatt medvirkning, spesielt i små arbeidsmiljø der det er lett å bli oversett.

Vi registrer ikke vesentlig uenighet yrkesgrupper imellom når det gjelder praktisering av smittevernregler. Det er heller ulikhet mellom personer ut fra deres holdninger og livssituasjon. Noen er sårbare, og redd for pandemien, mens andre har en mer offensiv holdning. Det kan slik bli en viss uenighet mellom de som vil «tøye strikken» og de som «vil adlyde». Spenningen var størst i første fase av pandemien, før man fikk etablert felles kriseforståelse.

Samlet ser vi en profesjonalisering ved at pandemien har tydeliggjort bestemt stillingskategoriers ansvar. Det gjelder spesielt prost og prest. For andre stillingskategorier har det vært en motsatt effekt, ved at nye arbeidsoppgaver har blitt utført av personer som har hatt tid og realkompetanse, uavhengig av profesjon og stillingsbeskrivelse.

\section{Spørreunders $\varnothing$ kelse blant valgte FR-ledere}

I dette avsnittet presenterer vi analyse av utvalgte svar på spørreundersøkelse blant fellesrådsledere. ${ }^{11}$ Dette kan sees som en utdyping av perspektivet «demokratisering». Informantene representerer fellesråd med variert størrelse. Noen har bare ett sokn (der FR og MR er overlappende), mens andre er fra store kommuner med flere sokn. Vi

\footnotetext{
11 Vi velger ut svar på de spørsmål som er spesielt relevant for vår problemstilling. Andre deler av materialet fra spørreundersøkelsen vil etter planen bli analysert og drøftet annet sted.
} 
har i denne analysen spesielt oppmerksomhet på data som belyser de demokratisk valgt ledere sin rolle og oppgave under pandemien. Dette er både analyse av svar på de kvantitative/standardiserte spørsmål og svar på åpne spørsmål.

Forst til de standardiserte sporsmailene. FR-ledere har i hovedsak forholdt seg til sine daglige ledere i sitt arbeid med pandemien, både når det gjelder å få informasjon og i utøvelse av sitt verv. De aller flest fikk sin informasjon om koronaen i første fase enten fra egen kirkeverge (KV) eller offentlig informasjon (ganske jevnt fordelt). For videre oppdatering senere i pandemien fikk de fleste (3/4) informasjon fra kirkelig ledere (KV og prost/sokneprest). Det er et lite mindretall (ca. 15\%) som ikke har lest den sentrale smittevernveileder. Det er et stort flertall (tre av fire) som opplever at arbeidet med smittevern i hovedsak er å følge nasjonale regler, og at det $\mathrm{i}$ liten grad gir rom for «kirkepolitikk», lokale valg. Det er et enda større flertall (ca. $83 \%$ ) som mener at det er kirkevergen som lokalt har hatt hovedansvaret for å fortolke de sentrale smittevernreglene. Se tabell 1.

Tabell 1: Oppfatning av hvem som har hatt lokalt hovedansvar for å tolke nasjonale smittevernveileder.

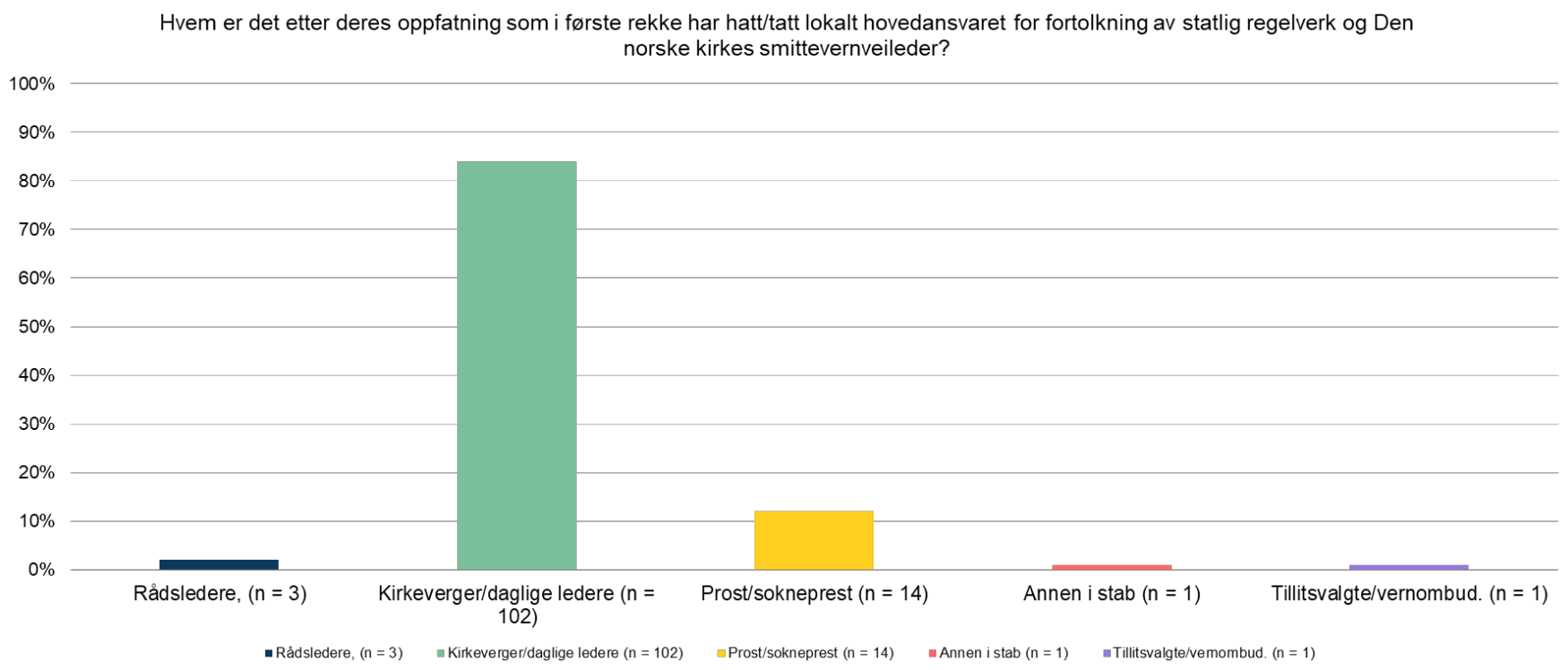

Samtidig som FR-ledere i hovedsak viser en tilbaketrukket rolle under pandemien, har de vært oppdatert og til en viss grad involvert. Ca. 1 av 4 sier de har vært med på beslutninger om lokale smittevernregler, mens de fleste har vært i dialog med KV, men ellers lite direkte involvert. Se tabell 2. 
Tabell 2: Sporsmål om i bvilken grad og på bvilken måte FR-leder har vart med på beslutning om smittevernregler lokalt.

På hvilken måte har du som fellesrådsleder vært med på beslutninger om smittevernregler i den lokale kirke?

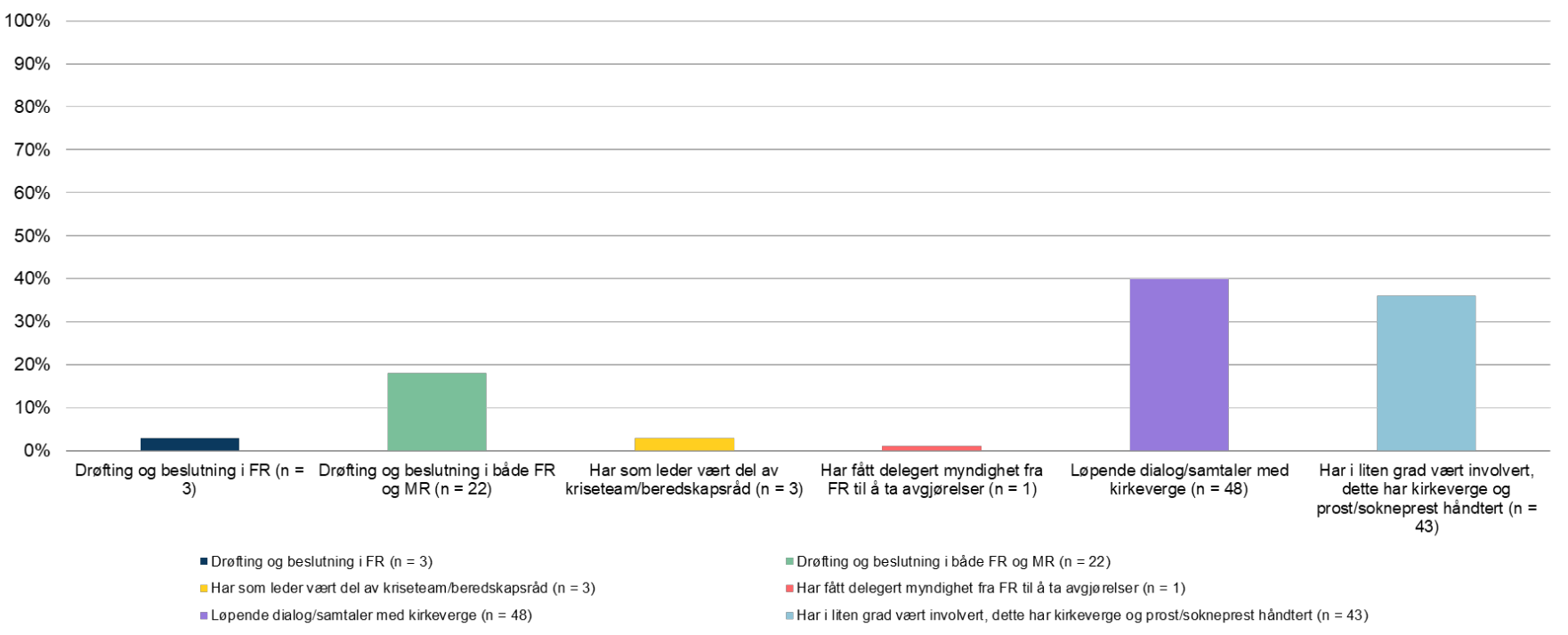

Det er tilsvarende fordeling mellom FR-ledere når vi spør dem om deres oppfatning av menighetsrådenes deltakelse og involvering. Noen har vært med i beslutninger, men de flest er bare blitt holdt orientert om daglig leder/kirkeverge sine beslutninger. Det rapporteres også om liten grad av spenninger eller konflikt i den lokale kirke, mht. smittevernregler. Ca. 3 av 4 mener det ikke har vært uenighet mellom ulike lokale aktører om fortolkning av regelverk eller praksis lokalt.

Vi registrerer en viss uklarhet om ansvarsfordeling mellom lokale ledere. Ca. $16 \%$ av informantene sier at de opplever at det er uklar forståelse av rollene til MR/FR og prest/prost, mens ca. $60 \%$ svarer nei på dette. Se tabell 3.

Tabell 3: Svar på opplevelse av uklarhet $i$ ansvarsforbold mellom lokale ledere

Mener du håndteringen av pandemien har avdekket uklarheter i ansvarsfordelingen mellom menighetsråd/menighetsrådsleder, fellesråd/kirkeverge, sokneprest og prost?

$100 \%$

$90 \%$

$80 \%$

$70 \%$

$60 \%$

$50 \%$

$40 \%$

$30 \%$

$20 \%$

$10 \%$

$0 \%$

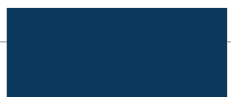

$\mathrm{Ja}(\mathrm{n}=19)$

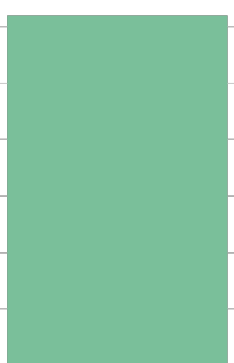

Nei $(n=74)$

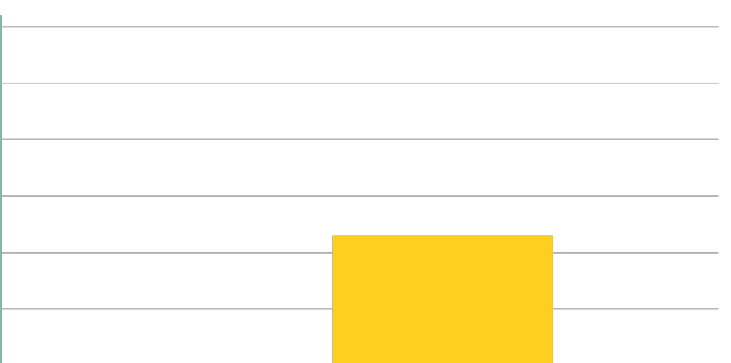

Har ingen klar formening $(n=27)$ 
Uklarhet i roller betyr imidlertid ikke nødvendigvis at det er uenighet mellom daglig leder og valgt leder/organ. Flere utsagn peker i retning av at tydelige anbefalinger og retningslinjer fra offentlige myndigheter har vært en god forutsetning for klarhet:

Kommunen her har vært tydelige i sine anbefalinger, basert på nasjonale retningslinjer. Det har gjort jobben mye enklere for administrasjonen både i gjennomføring og å skape felles forståelse.

Samtidig pekes det dels på at god dialog og avklarte roller og ansvar, har gitt gode prosesser med god kommunikasjon. Slik har lokale ledere etablert en felles forståelse av saken og de utfordringene man står overfor. Dels gis det også uttrykk for at daglig leder, kirkeverge, har gjort en god jobb med håndteringen og dermed skapt klarhet og ryddighet $i$ ansvarsdeling og gjennomføring. Tilsvarende gis også prost og prest ros der ting har fungert godt for å ha bidratt til en god dialog og felles forståelse av utfordringen.

Selv om et flertall av de som har gitt kommentarer pekte på at ting fungerte greit, var det likefullt en god del som pekte på at det har vært uklarhet. I denne gruppen nevnes spesielt at de demokratiske organer i liten grad har vært involvert. Andre har pekt på at strukturelle faktorer spiller inn, med mangel på kapasitet i rådene til å håndtere denne type saker:

Et problem er at rådene er kollegiale organer, uten ansatt administrativ ressurs.

(...) $\mathrm{Da}$ er vi dårlig rigget for denne type saker og det går ut over kvaliteten i vedtakene som gjøres.

Noen peker på at det kan være uenighet i fortolkning av retningslinjer, for eksempel ved at kirkeverge og prest/prost tar ulike valg. Uklarhet oppstår særlig når saksfelt er $\mathrm{i}$ grenseflaten for hvem som har ansvar. Når tilsatte ledere har tatt beslutninger, gir enkelte uttrykk for at rådenes «strategiske rolle blir nullet ut». Flere peker også på at de generelt føler det er uklart hvem som har ansvar på konkrete områder, og det reises også spørsmål om hvorvidt biskopen kan gripe inn og bestemme over kirkelige handlinger uten at menighetsrådet er involvert.

Det er en mindre andel $(8 \%)$ av de som har svart som sier at pandemien har avdekket spenninger/uenighet mellom valgt leder og ansatte ledere. Av konkrete saker nevnes noe av det samme som er nevnt tidligere bl.a. uenighet om konkrete tiltak, og tolkning av regelverk. Typiske utsagn er:

- Ulik tolkning av regelverk, og ulike tanker om 'alvoret' i situasjonen, f.eks. fare for smitte for hvem?

- FR-leder og MR-ledere har i liten grad vart informert for beslutninger er tatt.

- Uenighet knyttet til krisestabs avgjorelser.

Det er svært få valgte FR-ledere (bare én av informantene) som har hatt ansvar for utadvendt informasjon om smittevern. Det er kirkeverge eller prest/prost som i all hovedsak har hatt denne rollen.

Når vi spør hva de valgte FR-ledere mener skulle vært annerledes eller ønsker for femtiden, sier de fleste at de er fornøyde med den rollen de har hatt. Det er et relativt lite mindretall som uttrykker ønske om å være mer aktivt med $\mathrm{i}$ beslutninger, $\mathrm{i}$ beredskapsråd og ekstern informasjon, enn det som har vært tilfelle. Det er også enkelte som minner om at valgt leder ikke har ressurser eller frikjøpt tid til å gå inn i en aktiv rolle. 
Når vi spør om hvilken oppgave og rolle informantene mener valgt leder bør ha, var det 90 av de 130 informantene som hadde besvart med utdypende tekst, varierende fra noen få stikkord til et resonnement over flere setninger. Eksempler på korte stikkord er utsagn som «medansvarlig» eller «ledende», mens et mer utfyllende svar var:

Min rolle som valgt leder har siden jeg begynte vært å følge opp kirkevergen, så vi har samtaler ca. to ganger per uke, i tillegg til møter i FR, AU og ADMU. Ergo er jeg tett på hele tiden for å være en støtte og være informert, uten at jeg blander meg i kirkevergens daglige drift og hans ansvarsområde.

I analysen av disse svarene om leders rolle, delte vi dem i første omgang opp i tre hovedkategorier med sammenfallende meningsinnhold. For det første en kategori som kan omtales som Styrelederrollen. Blant svarene i denne kategorien, var det nettopp en del som sa at de opplevde å ha en styrelederrolle, og som sammenfalt med en del andre svar der det ble angitt at dette overlot man til kirkevergen ut fra en normal arbeidsdeling. Et typisk svar i denne kategorien var:

Rådsleder bør ta en, om ikke passiv, mindre sentral rolle i denne type kriser.

Det er daglig leder som har det daglige ansvaret for ansatte og virksomheten og bør være den sentrale personen med oversikt og oppfølging av tiltak.

Den neste kategorien kan omtales som Mellomledd-rollen, og synes å ha en noe mer aktiv rolle uten å tre tydelig fram på den offentlige arenaen. Ut over rollen som leder av rådet i møter, vektlegges det å være en kontinuerlig diskusjonspart med daglig leder. I tillegg angis det at valgt leder samarbeider med eller er bindeledd mellom ulike interne og/eller eksterne aktører. Ulike typer utsagn går igjen i denne kategorien, slik som «tett dialog med kirkeverge og sokneprester, orientert før beslutninger» eller «å være bindeledd mellom rådsmedlemmer (menigheter) og kirkeverge og prester».

Den siste kategorien svar gir uttrykk for en tydeligere og mer aktiv folkevalgt lederrolle, og kan omtales som den folkevalgte Aktor-rollen. Her angis at man enten har deltatt aktivt eller burde utøvd en tydeligere rolle i beslutninger. Flere peker på at dette følger av ansvaret som folkevalgt og at denne skal være en del av beslutningsprosessen. Et typisk svar i denne kategorien er:

Når det oppstår en krisesituasjon, bør en valgt leder være med i en krisestab. Dette for å holde seg oppdatert og informert om utviklingen og kunne svare media og andre interessenter hvis de skulle ta kontakt. Viktig at fellesrådsleder er samkjørt med og har samme informasjon som kirkeverge, det gjør det også lettere å være en støtte for daglig leder.

Svarene reflekterer både hvordan man mener situasjonen burde være og hvordan den faktisk har vært. Flere av svarene peker på at de eksisterende rammebetingelsene og pandemien i seg selv ikke gjør det mulig å fylle rollen som folkevalgt leder slik man ønsker: «Valgte ledere har i mange tilfelle ingen mulighet til å følge opp denne type kriser, og en er derfor avhengig av gode tilsatte ledere». Flere gir uttrykk for ambisjoner på vegne av rollen som folkevalgt leder, men at dette krever en videre gjennomtenkning av rollen:

Sett i forhold til det ansvaret vi har som valgte ledere, burde det ha vært avklart med oss hvilken rolle vi skulle ha. Det tette samarbeidet mellom prost og kirkeverge har fungert bra, men som leder har jeg blitt mottaker av informasjon 
om beslutninger som er tatt av andre. Det ville vært naturlig med en mer aktiv deltakelse. Systemet skal være handlekraftig, med det er verdt å tenke over demokratiets styringslinje i dette.

Fellesrådslederne viser tydelig forståelse av sin rolle som valgte ledere, og majoriteten av de som har svart på dette spørsmålet plasserer seg i kategoriene Mellomledd-rollen og Aktørrollen. Svarene varierer fra at man har vært holdt oppdatert og gitt innspill til at man har vært eller burde vært ledende i prosessen. Når det i mange tilfeller ikke har vært mulig å ivareta eller fylle en slik rolle, pekes det både på rammebetingelser i form av frikjøp, men også at det i liten grad har vært reflektert nok og tydelig nok om rollefordelingen i systemet. Sammenlignet med den uttegning som i litteraturen gjøres av rollen som politisk leder, er det langt igjen før valgte kirkelige ledere utøver kirkepolitisk lederskap. Pr i dag synes det å mangle en rolleforståelse som gir grunnlag for å utforme løsningsforslag eller å fronte beslutninger i en mobilisering av medlemmer og tilsatte. Dette overlates administrasjonen,

På spørsmålet om hva som har vært storste utfordringen under pandemien, nevner de aller flest utfordringen med stengte kirker og mangel på fysiske gudstjenester og annen virksomhet i menigheten. Flere uttrykker bekymring om engasjementet kan holdes opp og at folk kommer tilbake til kirken etter pandemien. Det er også enkelte som ser utfordringen med manglende planer og prosedyrer for å ta beslutninger: «Det er manglende instruksjonsmyndighet - ned til soknenivå.» «Det er behov for å definere krisestab lokalt for alle råd der daglig ledelse, valgt ledelse og fagledelse er representert, med mandat til å ta alle avgjørelser.» Noen utrykker frustrasjon over helsemyndighetenes detaljstyring overfor kirken, ved at det er «for lite mulighet for sjølstendige vurderinger».

På spørsmål om hva pandemien generelt har lart oss med tanke på fremtidig organisering av kirken, nevnes flere momenter som direkte berører det kirkelige demokrati eller rollefordeling mellom valgte ledere og ansatte ledere. Noen fremhever problemet med to arbeidsgiverlinjer. Det pekes på behovet for lokal forandring i ledelse: «Det bør være kort vei mellom styrende instans og menighet.» Det fremheves også at det både må være åpenhet for lokale variasjoner, en fleksibilitet, og én ledelse: «Det må være én ledelse for å unngå uklarheter. Viktig å ha avklarte ledelseslinjer når vanskelige beslutninger må tas raskt.» Det er også flere som peker på behovet for en god arbeidskultur og lagånd, samtidig som det er viktig med klare roller. Noen mener at rådsleder og demokratisk valgte generelt bør være mer delaktige: «Viktig å inkludere flest mulig i beslutningsprosesser. Involvere både fellesråd og menighetsråd mer (ikke bare ledere).» Enkelte trekker paralleller til hvordan det er i kommuner: «Det er forskjell i kommunene hvem som står fram med informasjon, ordfører, byrådsleder, smittevernlege og ganske sjelden rådmann. Rådslinjen må ikke bare settes på sidelinjen.» God kontakt og relasjoner mellom kirke og offentlige myndigheter er også noe som fremheves som viktig $i$ en kirkelig organisering.

Samlet ser vi at de valgte FR-ledere i stor grad er fornøyd med sin rolle, samtidig som et mindretall peker på uklarhet i rolleforståelse Pandemien har synliggjort noen dilemma i organisasjonen, samtidig som det har vært stor grad av enighet i selve saken - smittevern. Erfaringer fra denne krisetiden gir lederne grunnlag for refleksjon om en fremtidig kirkeorganisering generelt. 


\section{Analyse av utvalgte dokumenter}

Vi har hatt tilgang på aktuelle dokumenter og korrespondanser der korona-pandemien har vært behandlet. Det er bl.a. alle utgaver av smittevernveiledere, nyhetsbrev, pressemeldinger og informasjonsmøter, og også en rekke eposter knyttet til «beslutningsprosesser» mellom ulike ansatte.

Dokumentene avspeiler et konstruktivt samarbeid mellom ulike aktører i de sentralkirkelige organ. I dialogen mellom sentrale kirkelige aktører og offentlige instanser kommer det frem at de kirkelige aktører har stor tillit til og innordner seg etter de retningslinjer som kommer fra de offentlige myndigheter.

Vi har ikke funnet dokumenter som direkte omhandler de demokratisk valgte sin deltakelse i beslutningsprosesser. I «beslutningsdialoger» ang. smittvernsregler på epost mellom ulike kirkelige aktører er ingen folkevalgte ledere med, heller ikke i kopifeltet. Vi ser heller ikke at dilemma i smittevern har vært drøftet i de demokratiske organ. Møter i Kirkerådetets AU, spesielt i første fase av pandemien, fremstår som en formell behandling der konklusjonen var relativt opplagt. AU var det organet som hadde demokratisk valgte medlemmer som kunne samles på kort tid og hadde legitimitet til å avgjøre saker som tidligere var vedtatt i KM eller KR. AU godkjente også første utgave av smittevernveileder, versjon 1.1., der det vises til samarbeid internt $\mathrm{i}$ kirken og overfor myndighetene. I innledningen står bl.a.:

Smittevernveilederen er utarbeidet av Kirkerådet i samarbeid med Bispemøtet, KA - arbeidsgiverorganisasjon for kirkelige virksomheter og styret $\mathrm{i}$ Norges kirkevergelag. Veilederen har vært drøftet med aktuelle fagforeninger på kirkelig sektor og hovedverneombudet for prestene. Veilederen er vurdert av Barneog familiedepartementet 02.05.2020 og er i samsvar med Folkehelseinstituttets smittevernveiledning. Kirkerådets arbeidsutvalg har godkjent veilederen til bruk i Den norske kirke 04.05.2020. Veilederen vil bli oppdatert ved behov og nye versjoner erstatter tidligere versjoner. Veilederen ligger på kirken.no/korona og skal være tydelig merket med «sist oppdatert dd.mm.åååå»

Se ellers ovenfor «Krisehåndtering i Den norske kirke (Dnk) - en introduksjon.»

\section{DR $\varnothing$ FTING}

Ut fra analysen av materialet ser vi noen spenninger knyttet til beslutningsprosesser og de demokratisk valgte ledere. På grunnlag av den tredelingen vi har i analysen, innleder vi de ulike drøftingsavsnitt med noen slike spenninger eller dilemma. Vi starter relativt kort med kirken som korporativ og profesjonell, og legger så vekten på det som er vårt hovedanliggende, kirken som demokratisk organisasjon.

\section{Ytre press for $\emptyset$ kt korporativisering og profesjonalisering}

Kirken fremstår under pandemien som både styrbar og enhetlig, ved at lederansvar for ulike oppgaver og tilsatte har måttet skje gjennom samarbeid og koordinering. Krisesituasjonen har ført til en økt samhandling og samarbeid, på tross av at kirken er en organisasjon som ellers er relativt 
komplisert og med separerte beslutningsprosesser. Felles ledergruppe/beredskapsråd med de sentrale daglige ledere og felles smittevernveileder er et uttrykk for denne enheten.

Bildet er mer nyansert i den lokale kirke. Enkelte har pekt på at de to linjene forsterker problemet når rådene er forankret $\mathrm{i}$ kommunene. For eksempel kan prosten ta avgjørelser om gudstjenester når det eksisterer ulike retningslinjer om smittevern $\mathrm{i}$ ulike kommuner i prostiet. Det skaper uenighet om hvordan ting skal håndteres.

Vi ser at tydelighet i offentlig råd og retningslinjer har styrket og fremmet felles forståelse og gjennomføring i kirken. Det har skapt en situasjon der det det i stor grad gjelder å kommunisere det nasjonale smittvernsregler inn $i$ en kirkelig kontekst. Når sentrale ledere har opplevd det som en kamp å få forståelse for kirken/trossamfunnenes særpreg og oppgave i samfunnet, er det en frustrasjon som alle kirkelige ledere har kunnet stå sammen om. Det har ikke virket splittende, men heller samlende. Det er imidlertid grunn til å spørre om den raske aksept og overtagelse av offentlige myndigheters smittevernregler er uttrykk for en byråkratisering av kirkens ledelse i pandemien. Ville bildet vært noe annerledes om vurdering og implementering av smittevernregler $i$ kirken hadde vært gjenstand for kirkepolitisk behandling, og at valgte ledere hadde frontet synspunkter? Ville det da blitt mer brytning mellom ulike synspunkter, og enda større tyngde $i$ kritikken overfor offentlige myndighetens inngripen $i$ tros- og forsamlingsfriheten?

Pandemien har vært med på å tydeliggiøre roller og ansvar, samtidig som det også har skapt en viss usikkerhet for andre. På regionalt og lokalt nivå ser vi at prosten får en avgjørende rolle. Prosten blir utfordret til å være en tydeligere leder, ved å gi råd og ta beslutninger og ikke bare være støttende leder. Lokalt er det kirkevergen og daglig leder (der det er slike) som får en tydelig rolle. På den ene side har pandemien vært med på tydeliggjør de ansvarsoppgaver de ulike stillinger har. På den annen side har pandemien også tydeliggjort en viss uklarhet i ansvarsforhold. Dette er noe vi tenker bør drøftes nærmere i fremtidig organisering av kirken, slik flere informanter også har forventninger om.

Vi ser på flere punkter en parallell til det man fant også i den danske folkekirkens i første fase av pandemien. ${ }^{12}$ Forvaltningsstrukturen er blitt mer tydelig, og lokale medarbeidere forventer klare svar fra de overordnede. Prosten har også i den danske kirke fått en fremtredende rolle i pandemien.

Hvordan skal vi så forstå denne korporativisering og profesjonalisering, at kirken mer enn normalt har opptrådt enhetlig og samtidig fått klare ansvarsroller under pandemien? Det nærliggende svaret kan være at «en ytre utfordring virker samlende» og krever avklaring. Pandemien var noe som krevde raske og samordnede løsninger. Man hadde tydelige ytre rammer å forholde seg til, fra offentlige myndigheter. Selv om det er delt virksomhets- og lederansvar hadde man ikke tid til å drøfte eventuelle spenninger og uklarheter. Det krevdes handling fremfor refleksjon over roller. Så langt vi kan se, medvirket dette til at folkevalgte som i mindre grad hadde tilgjengelig tid, i liten grad ble involvert som beslutningstakere. Vi spør imidlertid om det var kort tid, bortsett fra $\mathrm{i}$ første nedstenging. Kom de ansatte ledere inn $\mathrm{i}$ en arbeidsmåte som holdt de demokratisk valgte utenfor prosessen også når det var god tid til å drøfte og beslutte?

12 Coronarapport DK, s. 13-14. 
Kan det være visse strukturelle forutsetninger som har vært avgjørende? I kirkelig sektor er det oftest prosten som representerer virksomheten offentlig når det gjelder saker som angående prestetjenesten. Vi ser at en korporativiseringen av kirken har styrket en profesjonalisering og slik også synliggjøring av den tilsatte lederrollen.

\section{Demokratisering}

Det har altså vært en tydelig forskjell mellom ansatte og valgte ledere, både når det gjelder beslutningsprosesser og synlighet i offentligheten. Mens ansatte ledere, som direktør, kirkeverge og prost har vært synlige, har demokratisk valgte ledere vært tilbaketrukket og lite synlige. Noen av de valgte ledere gikk bevisst inn i en slik rolle, men for de fleste ble det bare slik ut fra tradisjon. De ansatte oppleve ansvaret, tok initiativ og hadde kapasitet til å stå i prosessen. En viktig forklaring for at det ble slik lokalt, er at det lokale demokratiets rekkevidde ikke omfattet gudstjenesteliv og prestetjenesten. Samtidig viser materialet at heller ikke på nasjonalt eller regionalt nivå, der dette ansvaret er demokratisk forankret, ble folkevalgte involvert i særlig grad. Dette på tross av enkelte aktørers uttrykte ønske om slik deltakelse. Grunnen til dette tenker vi er todelt. Delvis på grunn av mangel på tilgjengelig tid og institusjonaliserte arenaer for de valgte ledere, og delvis ut fra praksis med at kirkens folkevalgte i liten grad framtrer i offentlig ledende posisjoner. Man blir hengende i en tankemodell som skiller for tydelig mellom politisk og administrativt ansvar. Om folkevalgte, politiske ledere, ønsker å prege beslutningsprosesser må de inngå i dialog med administrasjonen ved flere tidlige veivalg. Det krever en bevisst rolleforståelse omkring hvem som representerer et ansvarlig organ i en kirkelig offentlighet.

De fleste valgte ledere synes å være tilfreds med denne tilbaketrukne rollen. Det er enkelte unntak. Vi ser en viss geografisk variasjon her, da valgte ledere fra by/store kommuner samt nasjonalt nivå, i større grad ønsker å være delaktige enn det som er tilfelle i gristrengte strøk / små kommuner.

De folkevalgte ledere er påfallende fraværende i det offentlige rom når det gjelder informasjon om smittevernregler om man sammenligner med hva som er tilfelle $\mathrm{i}$ offentlig sektor (politikere i kommune og stat). Et nærliggende svar på hvorfor det er slik kan være at det demokratiske system er tilrettelagt som en arbeidsprosess med forberedelse til og drøfting i møter som avsluttes med kollektive avgjørelser. Det kan også trekke i samme retning at de kirkelige håndbøker og retningslinjene for rådenes arbeid, i stor grad legger til grunn at rådene arbeider gjennom møter. De blir dermed avhengige av at saker settes på dagsorden og at de gis sakspapirer som grunnlag for beslutning. Det synes å være lite tradisjon for en synlig demokratisk lederrolle, ut over det å lede møter. På lokalt nivå henger det også dels sammen med at viktige områder, særlig gudstjenester og kirkelige handlinger, har ligget utenfor de lokale folkevalgte råds myndighet.

Vi tror denne rollefordelingen vi ser også henger sammen med at det er uklart hva som skal være styring (styreleder sin rolle) og ledelse (daglig leders rolle), det som har vært omtalt som administrasjonsparadokset (Lo \& Vabo, 2020). De informanter som uttaler seg med en sterk demokratisk identitet og bevissthet (bl.a. enkelte FRledere og BR-ledere) setter ord på det vanskelige og uklare i rolleforståelse mellom valgt og daglig leder. Dette utfordrer til en nærmere drøfting og avklaring av hvilken rolle den valgte leder skal ha, både i en krisesituasjon som koronapandemien, men også 
mer generelt. En skjelning mellom styring og ledelse kan her være en konstruktiv tilnærming. Styret (og valgt leder) skal styre, mens daglig leder skal lede virksomheten (Bjelland et al., 2021).

Jevnført med de ansvarsområder som Masciulli og kolleger framhever (Masciulli et al., 2016), synes den vektlegging som knyttes henholdsvis til Styreleder og Mellom-ledd rollene å bidra til at man i mindre grad bidrar i utadrettede tiltak. Valgte ledere kan være med i definering av utfordringer og løsninger, men vil i liten grad verken artikulere eller mobilisere medlemmer for løsning. De informantene som gav uttrykk for en ønsket Aktørrolle, trenger antakelig strukturell støtte gjennom frikjøp og definerte arenaer for representasjon på sitt ansvarsområde.

Når vi ser til det offentlige, slik som kommuner, er det en annen kultur for politisk deltakelse, samtidig som det er en tydeligere skjelning mellom styring og ledelse. Den valgte leder/ordfører blir som en selvfølge med i et kommunalt beredskapsråd eller kriseledelse. Ordførere er vanligvis frikjøpt på heltid fra annet arbeid, mens valgte ledere i kirken vanligvis bare har møtegodtgjøring. Vi spør om forskjellen også henger sammen med en mer avklart og tydeligere politikerrolle i det offentlige, der de valgte er både ombudspersoner (representerer folket) og beslutningstakere (styringsrollen). I kirken synes folkevalgtes rolle å særlig være knyttet til styringsrollen, mens ombuds- og representasjonsrollen er svakt utviklet. Vi tolker våre informanter slik at den tilbaketrukne rolle for de folkevalgte ikke er resultat av en gjennomtenkt strategi eller beslutninger i de valgte organ. Det er noe som er blitt slik, gått inn i en tradisjon. De ansatte ledere har på sin side agert ut fra hva de tenker er deres ansvar i en krisesituasjon, og har «fylt rommet» uten å tenke over at det skulle/kunne være annerledes. En akutt situasjon tilsier heller ikke at man skal endre på tidligere rutiner eller holdninger. Samtidig synliggjøre pandemien noen dilemma og gir økt refleksjon om rolleforståelsen.

Når pandemien ble langvarig og man var i gang med å drøfte gjenåpning, ser vi tegn på at de folkevalgte i større grad ønsket å være delaktige. Det kan forstås ved at det er en mer rolig og forutsigbar prosess å åpne opp enn å stenge ned.

Vi ser ikke bort fra at enkelte folkevalgte sitt ønske om mer delaktighet også kan henge sammen med personlig engasjement og ambisjoner for det verv man er valgt til. Slike forskjeller synes også å henge sammen med ulike idealer for det kirkelige demokrati. I et «organisasjons-demokrati» har valgte ledere tradisjonelt en tilbaketrukket rolle i offentligheten. I et «parti-demokrati» er valgte ledere oftest mer fremtredende, og har også behov for å være synlige i det offentlige for å få tillit. En fornyet interesse for folkevalgt lederskap kan derfor også forstås som en effekt av den pågående framvekst av ulike lister ved sentrale valg i Den norske kirke.

Vi har i denne artikkelen vært mest opptatt av beslutningsprosessen under og med selve pandemien. Man kan også spørre hva pandemien har gjort med det demokratiske arbeidet generelt, knyttet til også andre saksfelt.. Har det blitt et demokratisk underskudd i denne perioden, da det i hovedsak har vært digitale møter og flere møter har blitt avlyst eller utsatt? Hva kan det bety på lang sikt at de demokratiske organer har vært på «sparebluss» under pandemien? Dette ser spørsmål som venter på å bli utforsket senere. 


\section{KONKLUSJON}

Hva skal vi svare på spørsmålet: Hvordan har kirkelige ledere, sentralt, (regionalt) og lokalt, bandtert beslutningsprosessen med smittevernregler under korona-pandemien, spesielt med tanke på valgte lederes medvirkning?

De ansatte kirkelige ledere har håndtert smittevernregler under pandemien med stor tillit og lojalitet mot offentlige myndigheter. Det har gjennomgående vært en god samordning mellom ansatte ledere på alle nivå i kirken, der samarbeidet $i$ synes å ha fungert bra. Beslutningsprosesser har tilstrebet konsensus, og kirken har i stor grad fremstått som en sammenhengende organisasjon. Samtidig har arbeidsprosessen tydeliggjort noen uklare ansvarsforhold, spesielt i den lokale kirke.

Demokratisk valgte organ og ledere har hatt en tilbaketrukket rolle, og i liten grad vært med i beslutningsprosesser eller vært synlige i det offentlige rom. I stedet for å ivareta en representasjonsrolle, har de ivaretatt en mer tilbakelent rådslederrolle som kan minne om styrelederrollen i bedrifter og statsselskaper Vi spør om en styrking av kirkens korporativitet under pandemien har gått på bekostning av demokratiets rekkevidde. I den sentrale ledelse har Kirkerådets arbeidsutvalg (AU) tatt noen nødvendige beslutninger som gjelder rammebetingelser for kirkens arbeid og vedtatt den første smittevernveilederen. Det valgte kirkerådet har ellers ikke besluttet, men vært holdt orientert om smittevernveileder. For de aller fleste lokalt valgte ledere synes det å ha en tilbaketrukket rolle under pandemien vært tilfredsstillende. Men enkelte valgte ledere tenker at de burde vært mer aktivt involvert og delaktige i beslutningsprosesser. De kunne vært betydelig mer aktive både i problemidentifisering, løsningsutvikling og ikke minst i presentasjon og mobilisering for innsats. Denne avgrensningen av demokratiets rekkevidde kan dels forstås ut fra pandemiens særpreg, med behov for raske avgjørelser og handling. Samtidig mener vi at denne begrensning av demokratiets rekkevidde henger sammen med tradisjoner og forståelse av kirkens demokrati generelt. Dels har kirkedemokratiet blitt sett som et «møtedemokrati», med vekt på selve beslutningstakingen der iverksettingen overlates ansatte ledere. Dels har mangel på tid eller en institusjonalisert ombuds- og representasjonsrolle trukket i samme retning. Særlig på lokalt nivå henger dette også sammen med den institusjonelle deling av oppgaveansvar og en delt arbeidsgiverstruktur. Viktige områder har ligget utenfor lokaldemokratiets rekkevidde. De erfaringer som er gjort med demokratisk valgte organ og de valgte lederes rolle under pandemien, er noe som bør reflekteres over videre. Slik kan denne artikkelen være et innspill til det arbeidet som er satt i gang i Den norske kirke. ${ }^{13}$

\footnotetext{
${ }^{13}$ Kirkerådets demokratiutvalg skal bl.a. se på arbeidsbetingelser for de valgte ledere (Ref. note 11).
} 


\section{LITTERATUR}

Askeland, H. (1998). Leder og lederroller. KIFO Rapport 7. Tapir.

Askeland, H. (2001). Den kirkelige rådsstrukturens teologiske og demokratiske legitimitet: Trekk av meningsbrytninger i siste del av forrige århundre. I J. O. Ulstein \& P. M. Aadnanes (Red.), "Jeg gikk meg over sjo og land ..." (s. 267-289). Kyrkjefag Profil nr 1. Tapir Akademisk Forlag.

Askeland, H. (2012). Menigheten som organisasjon og trossamfunn. Organisasjonsteoretiske grunnperspektiver og forståelsen av menighet i endring. I E. Birkedal, H. Hegstad \& T. S. Lannem (Red.), Menighetsutvikling i folkekirken: Erfaringer og muligheter (s. 137-152). Prismet bok. IKO Forlaget.

Askeland, H., \& Øystein D. (2021). Forholdet mellom demokratiske valgt og tilsatt ledelse i kirkelig og ideelle organisasjoner. I J. A. Bjelland, Ø. Dale \& H. Askeland (Red.), Ledelse og organisering $i$ kristne virksombeter (s. 84-95). KA.

Den Norske Kirke \& KA (u.å.). Smittevernveileder for Den norske kirke. Siste versjon: https://kirken.no/nb-NO/om-kirken/for-medarbeidere/infotilmedarbeidere $/$ info $\% 20$ til $\% 20$ medarbeidere $/$ ny $\% 20$ smittevernveileder $\% 200 g \% 20$ nye $\% 20$ nasjonale $\% 20$ regler/ Endringslogg: https:/ kirken.no/nn-NO/om-kirken/for-medarbeidere/infotilmedarbeidere/smittevernveileder $\% 20$ for $\% 20$ den $\% 20$ norske $\% 20$ kirke/endringslogg/

Enderud, H. (1985). Beslutninger i organisationer - $i$ adfardsteoretisk perspektiv. Fremad

Folkekirkens Uddannelses- og Videnscenter. (2020). När folkekirken skal spille efter reglerne - men uden for banen: Folkekirkens haindtering af coronaperioden i forairet 2020. https://www.fkuv.dk/undersoegelser-og-viden/projekter-undersoegelser-ograpporter/coronarapport

Grimstad, F., \& Askeland, H. (1999). Den lokale kirkes styrmenn og -kvinner - sitter de ved roret? I. M. H. Hougsnæs (Red.), Kirken, lekfolket og presteskapet: Kirkeliv og kirkereformer i Den norske kirke ved tusenårsskiftet (s. 40-58). KA

Grimstad, F. (2021). Demokrati i kirke og menighet. I S. Sirris \& H. Askeland (Red.), Kirkelig organisering og ledelse: Et verdibasert og praksisorientert perspektiv (s. 107-133).

Cappelen Damm Akademisk. https://doi.org/10.23865/noasp.129

Hodøl, H.-O., Emanuelsen R., \& Johannessen, G. C. (2021). Kirker, korona og nettbaserte gudstjenester. Norsk medietidsskrift, 28(2), 01-21.

https://doi.org/10.18261/ISSN.0805-9535-2021-02-02

Hodøl, H.-O., \& Sæbø, E. (2021). Seernes opplevelse av nettbaserte gudstjenester. Kirke Og Kultur, 1, 31-54. https://doi.org/10.18261/issn.1504-3002-202101-04

KA. (2020). Håndbok for kirkelige rådsledere. https://www.ka.no/radslederhandboka Kirkerådet. (2019). Håndbok for menighetsråd og kirkelig fellesråd.

Kirkerådets kirke/stat-utvalg. (2002). Samme kirke - ny ordning: Om ny ordning av den norske kirke, med sarlig vek.t på forholdet mellom kirke og stat. https://kirken.no/nbNO/om-kirken/slik-styres-kirken/kirkeordning/kirkestat-utvalget-1998-2002/

Hodøl, H.-O., Emanuelsen, R., \& Johannessen, G. C. (2021). Kirker, korona og nettbaserte gudstjenester. Norsk Medietidsskrift, 28(2), 01-21. https://doi.org/10.18261/ISSN.0805-9535-2021-02-02 
Lo, C., \& Vabo, S. I. (2020). Administrasjonsparadokset. Farvel til timeglassmodellen? I Folkevalgt og politisk leder (s. 62-89). Cappelen Damm Akademisk. https://doi.org/10.23865/noasp.80

Masciulli, J, Molchanov M. A., \& Knirght W. A. (2016). Political leadership in context. I M. A. Molchanov \& J. Masciulli (Red.). The Ashgate Companion to political leadership, (pp 23-48), Routledge.

Sirris, S. (2021) Stort ansvar, liten myndighet. Menighetsrådet som styringsorgan. Tidsskrift for Praktisk Teologi, 38(2), 39-57. https://doi.org/10.48626/tpt.v38i2.5448

Sirris, S., Askeland H., \& Grimstad F. (2021). Utviklingstrekk i organisering og ledelse i Den norske kirke. I S. Sirris \& H. Askeland (Red.), Kirkelig organisering og ledelse: Et verdibasert og praksisorientert perspektiv (s. 59-82). Cappelen Damm Akademisk. https://doi.org/10.23865/noasp.129

Erling Birkedal, f.1954, førsteamanuensis emeritus i praktisk teologi ved MF vitenskapelig høgskole. Forskningsfelt: Ekklesiologi og menighetsutvikling. Endring i individuell religiøs tro. Utvalgte publikasjoner:

Birkedal, E. (2020). Religiøsitet fra barndom til voksen. Tretten livshistorier om tro og livstolkning. Prismet bok. IKO-Forlaget.

Birkedal, E., \& Lannem, T. S. (2019). Kirkelandskapet i Norge i endring - utfordringer til Den norske kirke. Norsk tidsskrift for misjonsvitenskap,73(1), 8-22. https://doi.org/10.48626/ntm.v73i1.4436

Birkedal, E, \& Sirris, S. (2018). "Så lenge vi er med i utviklingsprosjekt skjer det noe!" Ti års erfaring med systematisk menighetsutvikling i Den norske kirke i en kontekst av ekklesiologisk og organisatorisk endring. Dansk Tidsskrift for Teologi og Kirke, 45(3), 213-237.

Birkedal, E. (2015). Forankring og forandring: En analyse og drøfting av erfaringer med systematisk utviklingsarbeid i menigheter i Den norske kirke i perioden 2011-14. Tidsskrift for praktisk teologi, 32(2), 18-33.

Harald Askeland, f. 1963, har for tiden et engasjement som fagdirektør i KA Arbeidsgiverorganisasjon for kirkelige virksomheter og er professor II i organisasjons og ledelsesfag ved Høyskolen i Østfold. Hans forskningsfelt er knyttet til reform og omstilling, lederjobb og lederroller, samt ledelse som praksis. Utvalgte publikasjoner:

Askeland, H., \& Sirris, S. (Red.). (2021). Kirkelig organisering og ledelse. Cappelen Damm Akademisk.

Askeland, H., Løvaas, B. J., Espedal, G., \& Sirris, S. (2020). Understanding Values Work. Institutional perspectives in organization and leadership. Palgrave Macmillan. https://doi.org/10.1007/978-3-030-37748-9

Askeland, H., \& Aadland, E. (Red.). (2017). Verdibevisst ledelse. Cappelen Damm Akademisk 
Askeland, H. (2021). Hva er ledelse? Om å forstå ledelse og utøve lederrollen i kirkelige og trosbaserte organisasjoner. I J. A. Bjelland, Ø. Dale \& H. Askeland (Red.), Ledelse og organisering $i$ kristne virksombeter. KA.

Askeland, H., \& Hegstad, H. (2021). Tjenesten med å lede. Teologiske og ledelsesfaglige perspektiver på kirkens ledere. I J. A. Bjelland, Ø. Dale \& H. Askeland (Red.), Ledelse og organisering $i$ kristne virkesombeter. KA. 